\title{
Transition from Physical Design Studio to Emergency Virtual Design Studio. Available Teaching and Learning Methods and Tools-A Case Study
}

\author{
Elżbieta Komarzyńska-Świeściak ${ }^{1, *(1)}$, Britt Adams ${ }^{2}{ }^{\mathbb{D}}$ and Laura Thomas ${ }^{2}$ \\ 1 Faculty of Architecture, Wrocław University of Science \& Technology, 50-370 Wrocław, Poland \\ 2 Department of Educational Studies, Ghent University, B-9000 Ghent, Belgium; britt.adams@ugent.be (B.A.); \\ laura.thomas@ugent.be (L.T.) \\ * Correspondence: elzbieta.komarzynska-swiesciak@pwr.edu.pl
}

Citation: Komarzyńska-Świeściak E.; Adams, B.; Thomas, L. Transition from Physical Design Studio to Emergency Virtual Design Studio. Available Teaching and Learning Methods and Tools-A Case Study. Buildings 2021, 11, 312. https:// doi.org/10.3390/buildings 11070312

Academic Editor: Hernan Casakin

Received: 2 May 2021

Accepted: 15 July 2021

Published: 20 July 2021

Publisher's Note: MDPI stays neutral with regard to jurisdictional claims in published maps and institutional affiliations.

Copyright: () 2021 by the authors. Licensee MDPI, Basel, Switzerland. This article is an open access article distributed under the terms and conditions of the Creative Commons Attribution (CC BY) license (https:// creativecommons.org/licenses/by/ $4.0 /)$.

\begin{abstract}
At the core of architecture education are the design studio classes, where students test ideas, build physical models, and propose design projects in a shared creative environment. The COVID-19 pandemic in 2020 created a large disruption of this status quo and required a major shift in the whole experience of teaching and learning at design studios. Using a case study approach, the present paper describes the systematic process of translating Physical Design Studio into emergency Virtual Design Studio and how it has been perceived by students enrolled in the investigated courses. The focus was primarily on those tools and methods that were intended to compensate for traditional workshop methods (for example the tactile exercise of physical model making and pin-up board presentations). To meet this objective, available tools for performing Virtual Design Studio were assessed using experiences of Design Studio instructors on the one hand and students' surveys on the other hand. The study's results can be used as recommendations on how to optimally implement a transition from a Physical Design Studio environment to teaching a digital remote design studio. Furthermore, the results also add to creating design guidelines for setting up blended architecture education post-COVID-19.
\end{abstract}

Keywords: architecture education; online teaching; virtual design studio; COVID-19; remote collaboration; educational technology

\section{Introduction: Theoretical Framework}

\subsection{What Is a Design Studio?}

The process of learning to design is the most important stage of architectural education. Therefore, the Design Studio (DS) is still the core element of degree programs at architecture schools [1]. Tokman and Yamacli emphasize that the architectural design studio is an important learning process, "which aims to shape the architectural sensitivities of students and to develop their communicative abilities as well as their problem-solving skills" [2] (p. 245). Put differently, DS can be seen as a class in Bachelor and/or Master Architecture programmes in which learners receive hands-on instruction in architectural design, challenging them to apply all the theoretical knowledge and technical know-how gained from other courses in the programme [3-5]. In fact, a design studio is characterized by the absence of a clear distinction between theory and practice [6]. Aa result, the architectural theoretical knowledge and practical skills are obtained through a student-centred learning process of creating a design project, such as an urban space or a specific building [7]. In line with the (socio-)constructivist learning theory, architectural students are supposed to actively (co-)construct or make their own knowledge rather than passively accept information presented by the teacher-e.g., [6,8,9]. By translating this constructivist idea into architectural education, the learning process usually takes place in a flexible physical space that enables various activities such as collaborative or personal work, group 
discussions, seminars, the tactile exercise of physical model making based on design problems in the real world, student-tutor interactions, pin-up board presentations, and 'desk crits as well as juries' $[3,5,6,10]$. This 'learning by doing' approach allows students to develop decision-making capabilities, to explore their own talents, and to refine their own procedure and style of architecture design [6]. In this study, for the case in which a physical place is offered to the students to create a project throughout face-to-face interactions, the term Physical Design Studio (PDS) is used.

These PDSs are still the dominant approach in contemporary architecture education, as teaching architectural design is still mainly believed to require face-to-face student-teacher and student-student interactions [11]. Nevertheless, the Internet brings new opportunities to DS teaching [6], optimizing the DS approach is an ongoing process, and keeps evolving thanks to available technologies, among others architecture-related tools (e.g., BIM [12] or 'mycitylab' [13] and education-related applications (e.g., learning management systems like MOODLE [14]). Considering the emergence of numerous information and computer technologies (ICT), blended and Virtual Design Studios (VDS) have been used more frequently at Architecture Schools since the 1990s [6,10,15,16]. However, compared to the huge overall increase in online education worldwide in all types of disciplines, it is notable that both regional and metropolitan universities have been rather slow in offering design studios online [11]. What is known so far about the organization of design studios in online learning environments is summarized in the following sections.

\subsection{A Transition from PDS to VDS}

In the early days, VDS especially replicated the way in which traditional DS was organized. In fact, VDS allows us to do many of the things we do in face-to-face architecture education. Although VDS and PDS have the same learning objectives, the setting is different [6]. For example, as interaction and collaboration are key ingredients of DS, applications such as email, video conferences, and shared whiteboards can be used to stimulate geographically dispersed student-teacher and student-student conversations in online learning environments [17]. The use of these communication channels provides the opportunity to speed up the exchange of information [6]. Yee [18] indeed claimed that ICT offers great potential for design education, but it is - according to this author-not easy to achieve these benefits. A successful VDS is characterized by good technical support and an enthusiastic response by design students $[6,18]$. However, related to students responsiveness, Fleischmann [11] found that-while the concept of the digital native is widely used and leads to the assumption that 'tech-savvy' students would embrace online education-architecture students prefer studying design in a face-to-face environment when offered a choice between a fully online or offline DS.

Moreover, Kvan [19] discovered a very important pitfall as VDS expects from students that they work with people they barely know and whom they often do not trust. Especially when design communication is involved, students indeed acknowledge many advantages of PDS over VDS, such as facial expression and the ability to respond immediately. Students like to talk face-to-face about new design alternatives in the immediate vicinity of both instructor(s) and fellow students, who ask questions, show hands-on solutions to possible problems, offer feedback, and elicit reflection [11,20]. According to students, being physically present and getting immediate feedback also influence their motivation and level of attention during the design studio [11].

Both in PDS and VDS, the teacher is at the helm of the teaching and learning process, but in VDS an extra task is necessary, namely facilitating and coordinating the online exchange $[10,19]$. Along with the new technology and the initial excitement, VDS leads to frustration when instructors' and students' expectations are beyond the technological capabilities. Maher et al. [17] (p. 3) summarized it as follows: "we cannot just take a set of tools off the shelf and create a virtual design studio". Advancing technology alone will not create better student outcomes; developing fully online architectural design learning experiences requires a lot of effort from the instructor, who is not always well prepared 
for this task. Most instructors as well as students need time to adapt and to adjust when they are confronted with new technological tools and teaching methods [6,11]. In the next section, a possible middle ground is discovered that could bridge students' DS preferences (e.g., strong preference from design students toward a blended learning mode in design education [11]) on the one hand, and the online DS challenges for the instructors on the other hand.

\subsection{Blended DS as Middle Ground?}

In order to anticipate communication and collaboration issues during VDS, blended learning (or sometimes called 'hybrid learning') has increasingly found its way into architecture education. Although there is no single definition, Boelens, De Wever and Voet define the concept of blended learning as follows: "a deliberate 'blending' of face-to-face and online instructional activities, with the goal of stimulating and supporting learning" [21]. For example, Fleischmann [11] suggests that the studio environment can be augmented with video tutorials and a deliberate selection of social media platforms. The latter illustrates that there is an opportunity to bring social characteristics into an online Design Studio environment through the use of current technologies. Since it can be questioned whether well-known platforms such as Facebook and Instagram have the ability to facilitate efficient online collaborative work, there is a need to explore more suitable applications that support the specific nature of collaboration on design projects.

The first studies in the field of the blended design studio suggest that it suits well with the needs and preferences of today's architecture students, for example the ability to manage work, study, and social lives more flexibly [11,18,22], and that it fits with contemporary professional architectural design practices. The latter is made more explicit by Ionnou [10], who focuses upon the advantage of building networks via a blended design studio. In line with McClean's [23] assumption, Ionnou [10] describes the individual architecture student and practitioner as a life-long learner who is always interrelated with others, and thus interdependent. Compared to a PDS and a VDS, a blended, networked studio format expands the field of interaction; it provides students the opportunity to extend their knowledge base by interacting face-to-face or online with their peers on the one hand, but also with the community (e.g., various project stakeholders) on the other hand. With this method, students can discuss their views critically and openly in communities of people with common interests, which is advantageous for their own future professional career and network. Despite its expected benefits, blended learning has not yet been fully explored in architecture education and research [22].

\subsection{Significant Statement and Purpose of the Study}

This paper describes the process of redesigning Bachelor and Master urban design studios at Wroclaw University of Science and Technology. Due to the threat of COVID-19, this Polish university cancelled all face-to-face classes, including the PDS for architectural students. As described above, the idea of setting up VDS or blended DS is not new. The literature has already accentuated 'dos and don'ts,' and by taking these into account, it seems that the path of blended DS needs to be discovered. However, the responsible teachers had to deal with emergency remote teaching, and was obliged to move their courses online to help prevent the spread of the virus that causes COVID-19 [24,25]. That is why the educational redesign process resulted in an emergency VDS. This paper presents the lessons learned from the implementation of the redesigned DS for the future organization and optimization of architecture education.

\section{Materials and Methods}

In the current research, a case study approach was used. First, via a Teacher Design Team, the organization of the course in a remote manner was discussed in a systematic way. Second, the students of all three courses were questioned via an online survey with the purpose of evaluating the effectiveness of the applications and methods used in the VDSs. 
As the well-known research on cases of Hartley [26] and Yin [27] articulate, the purpose of a case study is not to bring about generalizable findings, but to add to the field by providing a comprehensive understanding of the phenomenon at study (see [28]). In this respect, though the small sample and the context-dependent nature (see [29] on case studies) of this research prevent generalization to the population, it does contribute significantly to the creation of new knowledge on VDS and can be used as a valuable input for further research on this topic. In what follows, the study's context and sample, and data sources and analyses are discussed more in depth.

\subsection{Context, Sample and Data Sources}

The current study reports on the implementation of VDS in three Architectural Design courses taught by the first author at the Faculty of Architecture of Wroclaw University of Science and Technology during the summer semester of 2019/2020 and winter semester of 2020/2021. Two of the courses are at Master level (i.e., "Public Building Design" and "Architectural Design-Service and Housing Development in the City") and one of the courses is at Bachelor level ("Public Buildings in City Centers"). During the majority of time in which these courses were taught, universities in Poland were in lockdown due to the COVID-19 pandemic [30]. In this respect, universities were being forced to transfer all teaching to online environments [31]. The reason for selecting the three aforementioned courses for this study is directly linked to this quick mandatory transfer to online teaching. As these courses are organized as DSs, they are particularly interesting to be used as field tests for transitioning the well-known teaching design methods and tools from PDS to the digital alternative of VDS. In transforming these courses, the main focus lied upon searching for new, innovative typologies and architectural scenarios enabling traditional activities of PDS in a remote way.

A key condition to deliver effective online learning is careful instructional design and planning, using a systematic framework for design and development. This implies that the design process of the VDS-including well-considered design decisions-have an impact on the quality of the instruction. Bearing this in mind, a Teacher Design Team (TDT) was set up to facilitate the design and development process of the emergency VDS. According to Handelzalts [32] (p. 7), a TDT is "a group of at least two teachers, from the same or related subjects, working together on a regular basis, with the goal to (re)design and enact (a part of) their common curriculum". In the context of the present study, the team consisted of five academic architectural teachers who also have the role of architectural design course instructors. All of them have at least five years of experience in teaching DS. Some of them had recently started exploring remote teaching.

Inspired by Adams, Rotsaert, Schellens, and Valcke [33], the ADDIE-model [34] was used to structure the redesign process of transforming the existing PDS into an emergency VDS (see Figure 1). The A of the acronym ADDIE stands for Analysis. In this phase of the design process, the members of the TDT scanned existing literature about VDS, looked for good practices on the Internet, and presented their own experiences with online architecture education to each other. Moreover, the first author of this paper, who acted as the coach of the TDT, followed an international professionalization programme called Masters of Didactics [35] in March 2020 - just before the start of the lockdown. This was a helpful experience in the context of the redesign process, as during this training university teachers are made familiar with many educational technology tools. Subsequently, in the Design-phase of the ADDIE-procedure, all team members were challenged to think about several feasible solutions by taking into consideration the input of the Analysisphase. Several options and tools were tested and discussed during an online meeting, which resulted into a blueprint of the emergency VDS. Additionally, during this phase, the principles presented in Figure 2 were considered. The second D of the acronym ADDIE symbolizes the Development phase, implying that TDT members turn this blueprint into an actual VDS by developing each element in detail. After individual work, the team members showed their concrete, worked-out ideas, allowing the others to give feedback 
in order to improve the VDS activities. Figure 3 shows how the several elements of PDS were translated into a VDS experience. Thereafter, the VDS was implemented during the summer semester of 2019/2020 and winter semester of 2020/2021. The first author of this research paper was also the main teacher during the Implementation phase of the VDS (see Section 2.3). Finally, in the Evaluation phase, students were asked for feedback at the end of the course. As Wragg [36] (p. 10) stated: "Working with design online is an iterative process, in which ideas about how to translate the on-campus experience online are tested, evaluated and revised, similar to the [architectural] design process itself". For that reason, implementation and evaluation are very important elements of ADDIE as these phases reveal concrete suggestions for improvement that can be considered when preparing the DS environment for the next academic year.

To have insight into the students' assessment of the VDSs, questionnaires were sent out to all 45 enrolled students via Google Forms and distributed via the online platform of the university, namely JSOS 2.0-Students' Service System of Wroclaw University of Science and Technology. With respect to students' consent to participate in the study, they were all thoroughly informed regarding each aspect of the study at the beginning of the first online gathering as well as through an introductory page at the start of the questionnaire. In particular, the students were briefed about the study's goals and practicalities and assured that their participation was entirely voluntary and did not have any influence on their final grades. They were also notified that the data collected through the research would be saved, processed, and reported in a completely anonymous way and that they could quit their participation at any time. Moreover, the students were provided with the contact details of the first author in case they had additional questions, needed more information regarding the research, and/or when they were interested in receiving a copy of the summary of the study's main results.

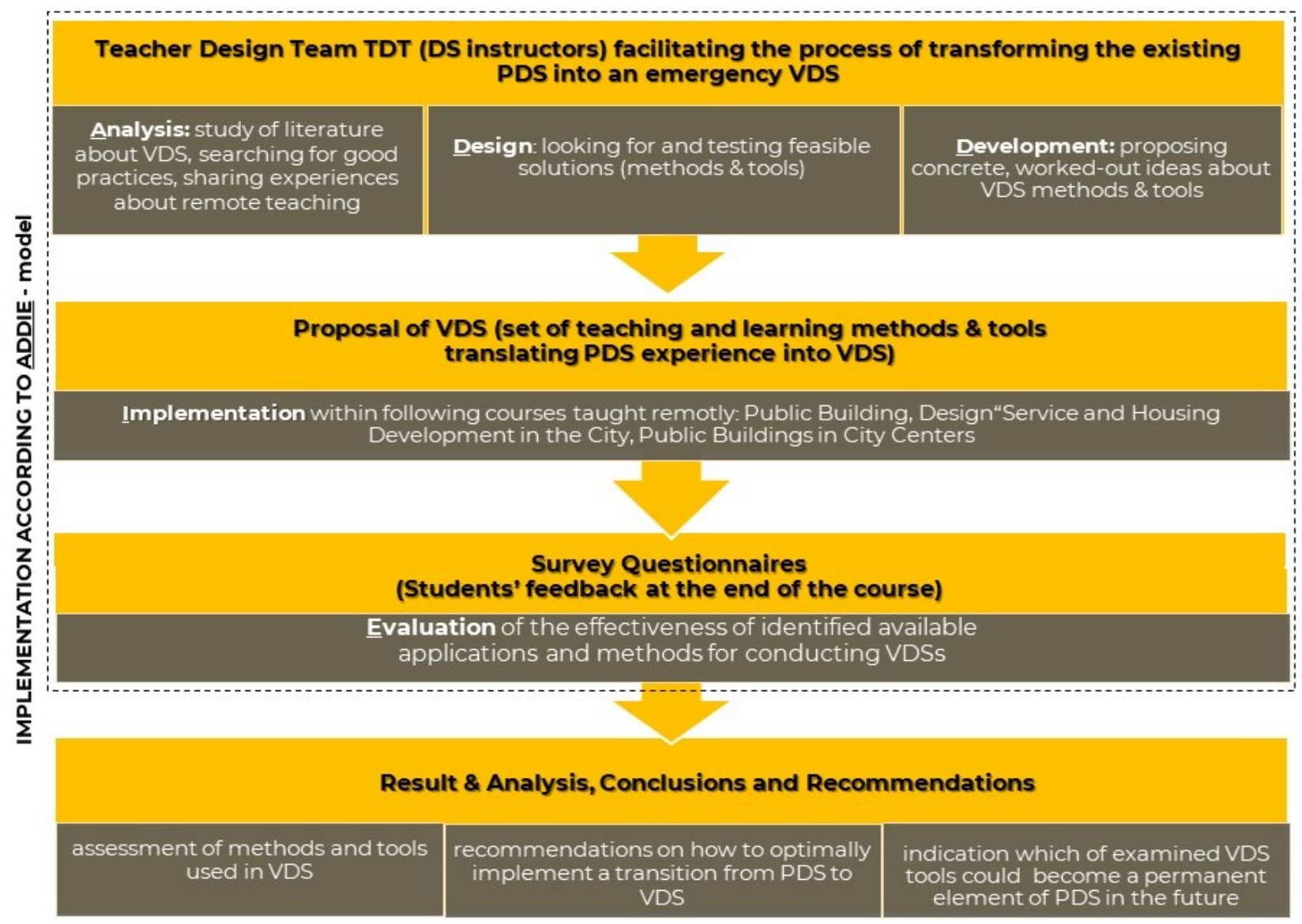

Figure 1. The structure of the redesign process of transforming the existing PDS into an emergency VDS, implemented according to ADDIE-model. 


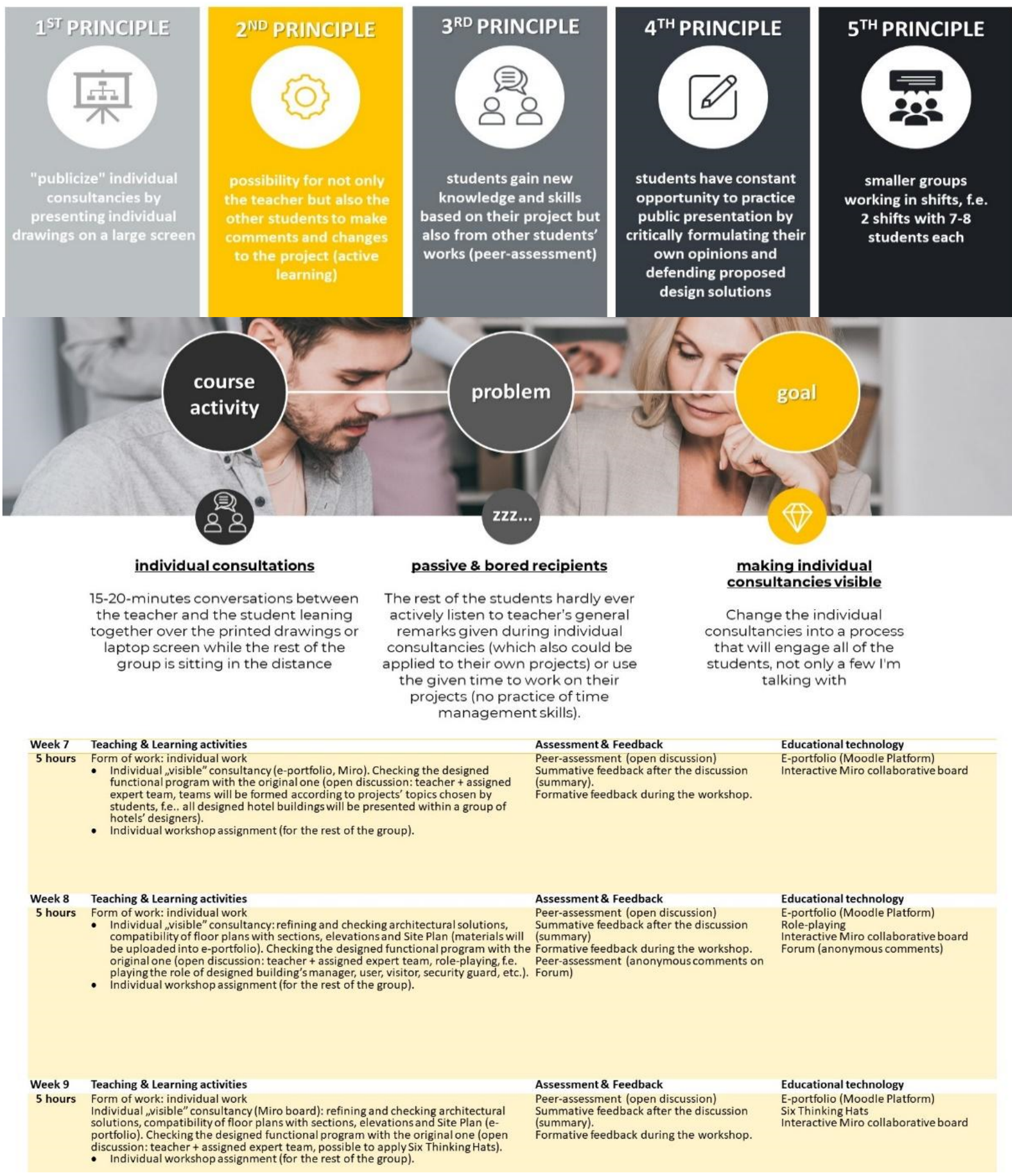

Figure 2. Educational Innovative Project “Individual consultations. Make them visible!" planned during the international Masters of Didactics program and introduced in VDS courses during spring semester 2019/2020 and winter semester 2020/2021. 

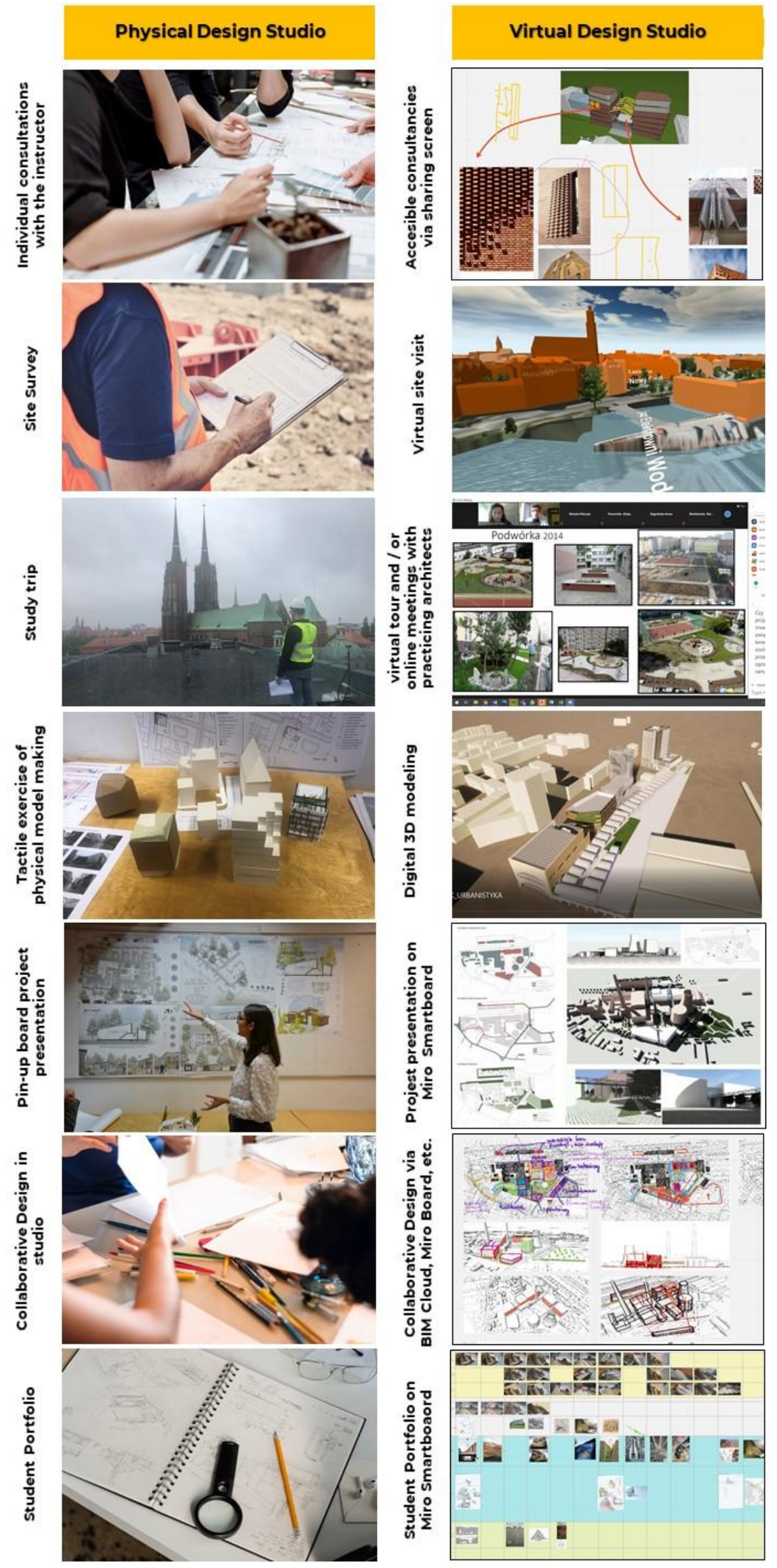

Figure 3. Common teaching and learning PDS activities and their VDS alternatives. 
The questionnaire focused on evaluating the effectiveness of identified available applications and methods for conducting VDSs. Focusing on the experiences of VDS in this group of students is interesting, as they already took part in PDSs several times during their academic trajectory; however, they had never before experienced participation in VDS. Zooming in on the survey more in depth reveals that it consists of 17 questions, 15 of which are 5-point Likert scale questions ranging from 1 ('strongly disagree') to 5 ('strongly agree') and two of which are multiple-choice questions. The first two questions focus on the level of satisfaction in terms of the size of the class group and the provided number of class hours. The following seven questions are about utilizing alternative teaching and learning methods in VDS-compared to the traditional methods used in PDS. The next four questions focus on the use of educational technology (Zoom, Moodle, Chat in Teams Messaging) as digital platforms for socialization and production. The final two questions (which have 3 optional answers) ask the students to give feedback about their individual experience in terms of their preferences with respect to PDS versus VDS.

\subsection{Data Analysis}

The survey received 42 responses, 14 of them being from participants of "Public Building Design" (1st semester Master students), 13 from participants of "Service and Housing Development in the City" (3rd semester Master students), and 15 from participants of "Public Buildings in City Centers" (7th semester Bachelor students). Students' answers on the survey were inputted in MS Excel. To grasp students' experiences with, and opinions about, the redesign of the course, basic descriptive analyses were used. Specifically, for all questions in the survey, three descriptive statistics were calculated. First, the mean was computed as a model to summarize our data (Field, 2009). Second, the standard deviation, which is the square root of the variance (Field, 2009), was estimated with the purpose of gaining insight into the spread of the data. Third, the coefficient of variation was also calculated. In doing so, an evaluation of the variability associated with the specific question could be obtained. Using these three descriptive analyses, gaining insight in students' evaluation of the redesign of the course was strived for.

\subsection{Case Study: PDS versus Emergency VDS at Wroclaw University of Science and Technology}

As can be deduced from the theoretical framework, the main learning objectives of a design studio are (1) improving students' decision-making capabilities as they need to build consensus around a specific design problem and turn different ideas and perspectives of several stakeholders into actionable design solutions, and (2) giving students the opportunity to explore their own architectural talents by refining their own design style and procedure in a safe learning environment with the support of the teacher and fellow students. That is why the line between theory and practice is blurred; students are challenged to bring together all the theoretical knowledge and practical know-how gained from other courses in their Bachelor/Master programme. Chen and colleagues [6] already emphasized that the learning objectives remain unchanged when a PDS is translated into $\mathrm{a}(\mathrm{n})$ (emergency) VDS, though the setting is different. This also applies to the case described in this study. For that reason, in the next paragraphs, the main similarities and differences between the settings of the original PDS and the emergency VDS are sketched. The exact details are illustrated in Figure 3 and Table 1. 
Table 1. Result of the TDT meeting: list of common teaching and learning methods and tools used in PDS translated into a VDS experience.

\begin{tabular}{|c|c|c|c|}
\hline & & $\begin{array}{l}\text { PHYSICAL DESIGN STUDIO (PDS) } \\
\text { Common Teaching and Learning } \\
\text { Methods \& Tools }\end{array}$ & $\begin{array}{l}\text { VIRTUAL DESIGN STUDIO (VDS) } \\
\text { Proposed Equivalents of PDS Teaching and Learning } \\
\text { Methods \& Tools }\end{array}$ \\
\hline \multirow[t]{3}{*}{1} & $\begin{array}{l}\text { TEACHING/ } \\
\text { LEARNING } \\
\text { ACTIVITY }\end{array}$ & $\begin{array}{l}\text { Individual consultations with the instructor } \\
\text { (face-to-face discussion within max. } \\
5 \text { people group) }\end{array}$ & $\begin{array}{l}\text { Accesible consultations via sharing screen (presenting the } \\
\text { discussion and visual effects of it to the whole classroom) }\end{array}$ \\
\hline & METHODS & $\begin{array}{l}\text { appointments with students, whiteboard } \\
\text { instruction, classroom discussion ( } 2-5 \text { students), } \\
\text { student-conceived projects, differentiated } \\
\text { instruction, reflective discussion }\end{array}$ & $\begin{array}{l}\text { appointments with students, remote collaborative board instruction, } \\
\text { classroom discussion (larger group of studetns involved), } \\
\text { student-conceived projects, differentiated instruction, } \\
\text { reflective discussion }\end{array}$ \\
\hline & $\begin{array}{l}\text { TOOLS \& } \\
\text { SOFTWARE }\end{array}$ & $\begin{array}{l}\text { printed drawings (limited due to printing costs), } \\
\text { sketching, physical modeling }\end{array}$ & $\begin{array}{l}\text { digital drawings (no limits), digital sketching (Miro, ZOOM, MS } \\
\text { Teams), sharing photos of hand-drawn sketches and physical models, } \\
\text { taking control of the screen (MS Teams), sharing digital 3D model (BIM } \\
\text { Cloud, Autdesk Share) }\end{array}$ \\
\hline \multirow[t]{3}{*}{2} & $\begin{array}{l}\text { TEACHING/ } \\
\text { LEARNING } \\
\text { ACTIVITY }\end{array}$ & Site Survey & Virtual site visit \\
\hline & METHODS & $\begin{array}{l}\text { field trip, photography, taking measurements, } \\
\text { visual observations, use of community or local } \\
\text { resources, interviewing }\end{array}$ & $\begin{array}{l}\text { virtual field trip, video lesson, visual observations, use of virtual } \\
\text { community or digital resources (e.g., Facebook Groups) }\end{array}$ \\
\hline & $\begin{array}{l}\text { TOOLS \& } \\
\text { SOFTWARE }\end{array}$ & $\begin{array}{l}\text { drawing tools \& clipboard, tape measure, laser } \\
\text { measure, camera \& mobile phone (video } \\
\text { walk-through, taking digital images, mobile } \\
\text { measuring apps) }\end{array}$ & $\begin{array}{l}\text { Google Earth, Google Maps, Copernicus, virtual 3D city model, GIS } \\
\text { Databases, Thinglink, Facebook, Instagram }\end{array}$ \\
\hline \multirow[t]{3}{*}{3} & $\begin{array}{l}\text { TEACHING/ } \\
\text { LEARNING } \\
\text { ACTIVITY }\end{array}$ & Study trip & Virtual tour and/or online meetings with practicing architects \\
\hline & METHODS & $\begin{array}{l}\text { field trip, photography, visual observations, on-site } \\
\text { duscussion, lecturing, guest speakers, case study, } \\
\text { interviewing }\end{array}$ & $\begin{array}{l}\text { virtual field trip (more locations are reachable), online duscussion, } \\
\text { lecturing, guest speakers (from all around the world), online } \\
\text { discussions, case study, interviewing }\end{array}$ \\
\hline & $\begin{array}{l}\text { TOOLS \& } \\
\text { SOFTWARE }\end{array}$ & $\begin{array}{l}\text { camera \& mobile phone (video walk-through, } \\
\text { taking digital images) }\end{array}$ & $\begin{array}{l}\text { Virtual Tour sites, Google Earth, Google Maps, Google Arts \& Culture, } \\
\text { virtual 3D city model, online videos, Zoom, MS Teams }\end{array}$ \\
\hline \multirow[t]{3}{*}{4} & $\begin{array}{l}\text { TEACHING/ } \\
\text { LEARNING } \\
\text { ACTIVITY }\end{array}$ & $\begin{array}{l}\text { Tactile exercise of physical model making (in } \\
\text { Design Studio) }\end{array}$ & $\begin{array}{l}\text { Tactile exercise of physical model making (at home) or digital 3D } \\
\text { modeling }\end{array}$ \\
\hline & METHODS & $\begin{array}{l}\text { hands-on activities (kinesthetic learning), direct } \\
\text { instruction, student-conceived projects, } \\
\text { differentiated instruction, reflective discussion }\end{array}$ & $\begin{array}{l}\text { hands-on activities (kinesthetic learning), direct instruction, } \\
\text { student-conceived projects, differentiated instruction, } \\
\text { reflective discussion }\end{array}$ \\
\hline & $\begin{array}{l}\text { TOOLS \& } \\
\text { SOFTWARE }\end{array}$ & sketches, physical models & $\begin{array}{l}\text { sketches, physical models, 3d photos and videos of the physical models, } \\
\text { 3D Design Software (e.g., Sketchup, Rhino, Archicad, Autocad, } \\
\text { Autodesk 3ds Max, Rhino 3D, Revit Architecture, Grasshopper) }\end{array}$ \\
\hline \multirow[t]{3}{*}{5} & $\begin{array}{l}\text { TEACHING/ } \\
\text { LEARNING } \\
\text { ACTIVITY }\end{array}$ & Face-to-face project presentation & Remote projest presentation \\
\hline & METHODS & $\begin{array}{l}\text { student presentation, debates, role playing, } \\
\text { reflective discussion, exhibits and displays }\end{array}$ & $\begin{array}{l}\text { remote student presentation, online debates, role playing, reflective } \\
\text { discussion, exhibits and displays }\end{array}$ \\
\hline & $\begin{array}{l}\text { TOOLS \& } \\
\text { SOFTWARE }\end{array}$ & whiteboard, pin-board, slideshow & slideshow, Prezi, 3d photo, Zoom, MS Teams, Miro Smartboard \\
\hline \multirow[t]{3}{*}{6} & $\begin{array}{l}\text { TEACHING/ } \\
\text { LEARNING } \\
\text { ACTIVITY }\end{array}$ & Collaborative design in studio & Remote collaborative design \\
\hline & METHODS & $\begin{array}{l}\text { one-time design task, team-building exercises, } \\
\text { collaborative learning spaces, problem solving } \\
\text { activities, hands-on activities, student-conceived } \\
\text { projects, DIY activities }\end{array}$ & $\begin{array}{l}\text { one-time design task, team-building exercises, collaborative learning } \\
\text { spaces, problem solving activities, hands-on activities, } \\
\text { student-conceived projects, DIY activities }\end{array}$ \\
\hline & $\begin{array}{l}\text { TOOLS \& } \\
\text { SOFTWARE }\end{array}$ & sketches, physical models, pin-board, slideshow & $\begin{array}{l}\text { digital sketches, collaborative 3D digtal models using 3D Design } \\
\text { Software (e.g., Sketchup, Rhino, Archicad, Autocad, Autodesk 3ds Max, } \\
\text { Rhino 3D, Revit Architecture, Grasshopper), Miro Smartboard, BIM } \\
\text { Cloud, Autdesk Share, slideshow }\end{array}$ \\
\hline
\end{tabular}


Table 1. Cont.

\begin{tabular}{|c|c|c|c|}
\hline & & $\begin{array}{l}\text { PHYSICAL DESIGN STUDIO (PDS) } \\
\text { Common Teaching and Learning } \\
\text { Methods \& Tools }\end{array}$ & $\begin{array}{l}\text { VIRTUAL DESIGN STUDIO (VDS) } \\
\text { Proposed Equivalents of PDS Teaching and Learning } \\
\text { Methods \& Tools }\end{array}$ \\
\hline \multirow[t]{3}{*}{7} & $\begin{array}{l}\text { TEACHING/ } \\
\text { LEARNING } \\
\text { ACTIVITY }\end{array}$ & Individual design in studio & Individual design in studio (performed remotly) \\
\hline & METHODS & $\begin{array}{l}\text { one-time design task, individual projects, } \\
\text { student-conceived projects, designated quiet space, } \\
\text { problem solving activities, hands-on activities, } \\
\text { DIY activities }\end{array}$ & $\begin{array}{l}\text { one-time design task, individual projects, student-conceived projects, } \\
\text { designated quiet space, problem solving activities, DIY activities }\end{array}$ \\
\hline & $\begin{array}{l}\text { TOOLS \& } \\
\text { SOFTWARE }\end{array}$ & sketches, physical models, pin-board, slideshow & $\begin{array}{l}\text { digital sketches, 3D digtal models using 3D Design Software (e.g., } \\
\text { Sketchup, Rhino, Archicad, Autocad, Autodesk 3ds Max, Rhino 3D, } \\
\text { Revit Architecture, Grasshopper), Miro Smartboard, slideshow }\end{array}$ \\
\hline \multirow[t]{3}{*}{8} & $\begin{array}{l}\text { TEACHING/ } \\
\text { LEARNING } \\
\text { ACTIVITY }\end{array}$ & $\begin{array}{l}\text { Case study (referenced architectural and urban } \\
\text { project) }\end{array}$ & Case study (referenced architectural and urban project) \\
\hline & METHODS & $\begin{array}{l}\text { research project, student presentation, set of } \\
\text { printed drawings, student-conceived projects }\end{array}$ & $\begin{array}{l}\text { research project, student presentation, set of printed drawings, } \\
\text { student-conceived projects }\end{array}$ \\
\hline & $\begin{array}{l}\text { TOOLS \& } \\
\text { SOFTWARE }\end{array}$ & whiteboard, pin-board, slideshow & $\begin{array}{l}\text { slideshow, Prezi, Zoom, MS Teams, Miro Smartboard, videos, materials } \\
\text { from presentation documented each step on the way and presented in } \\
\text { an organised way (e.g., on Moodle platform), Google Maps, virtual 3D } \\
\text { city model, GIS Databases, Thinglink }\end{array}$ \\
\hline \multirow[t]{3}{*}{9} & $\begin{array}{l}\text { TEACHING/ } \\
\text { LEARNING } \\
\text { ACTIVITY }\end{array}$ & Lecturing/Direct instruction & Remote lecturing/Direct instruction \\
\hline & METHODS & $\begin{array}{l}\text { lecturing, guest speakers (limitations), case study, } \\
\text { direct instrution }\end{array}$ & lecturing, guest speakers (no limitations), case study, direct instrution \\
\hline & $\begin{array}{l}\text { TOOLS \& } \\
\text { SOFTWARE }\end{array}$ & $\begin{array}{l}\text { whiteboard, pin-board, slideshow, interactive tools } \\
\text { (e.g., Kahoot!) }\end{array}$ & $\begin{array}{l}\text { slideshow, Prezi, 3d photo, Zoom, MS Teams, Miro Smartboard, } \\
\text { recorded lecture, materials form lecture and instructions documented } \\
\text { each step on the way and presented in an organised way (e.g., on } \\
\text { Moodle platform), interactive tools (e.g., Kahoot!) }\end{array}$ \\
\hline \multirow[t]{3}{*}{10} & $\begin{array}{l}\text { TEACHING/ } \\
\text { LEARNING } \\
\text { ACTIVITY }\end{array}$ & Student Portfolio & Digital Student Portfolio \\
\hline & METHODS & $\begin{array}{l}\text { student-conceived projects, problem solving } \\
\text { activities, individual projects, reseach project, } \\
\text { case study }\end{array}$ & $\begin{array}{l}\text { student-conceived projects, problem solving activities, individual } \\
\text { projects, reseach project, case study }\end{array}$ \\
\hline & $\begin{array}{l}\text { TOOLS \& } \\
\text { SOFTWARE }\end{array}$ & $\begin{array}{l}\text { set of hand-drawn and printed drawings \& } \\
\text { visualisations (limited due to printing costs) }\end{array}$ & $\begin{array}{l}\text { set of hand-drawn and printed drawings \& visualisations (no limits), } \\
\text { documented each step on the way and presented in an organised way } \\
\text { (e.g., on Moodle platform) }\end{array}$ \\
\hline
\end{tabular}

First of all, aims and outcomes of the course originally planned for PDS were kept in the newly designed emergency VDS. In the VDS, parallel to the PDS, the main aims for students were (1) to gain knowledge and skills concerning the principles and procedures of designing buildings (i.e., adapting the project to a given cultural and historic context and building law regulations) and (2) to practice architectural skills related to the design process (i.e., creating concept sketches, architectural models and using computer-aided design tools). Regarding student outcomes, in the PDS and VDS, the students were expected to draw urban and/or architectural projects in 1:500 scale (in case of a site plan) and 1:200/1:100 scale (in case of architectural models, plans, sections, elevations). However, even though the aims and outcomes of the course were the same, the presentation mode of students' projects radically changed. In particular, instead of presenting physical models, students were requested to prepare 3D-animations using computer tools. Moreover, instead of pin-board presentations, the students had to present their project outcomes using the virtual interactive board Miro (Figure 4). 


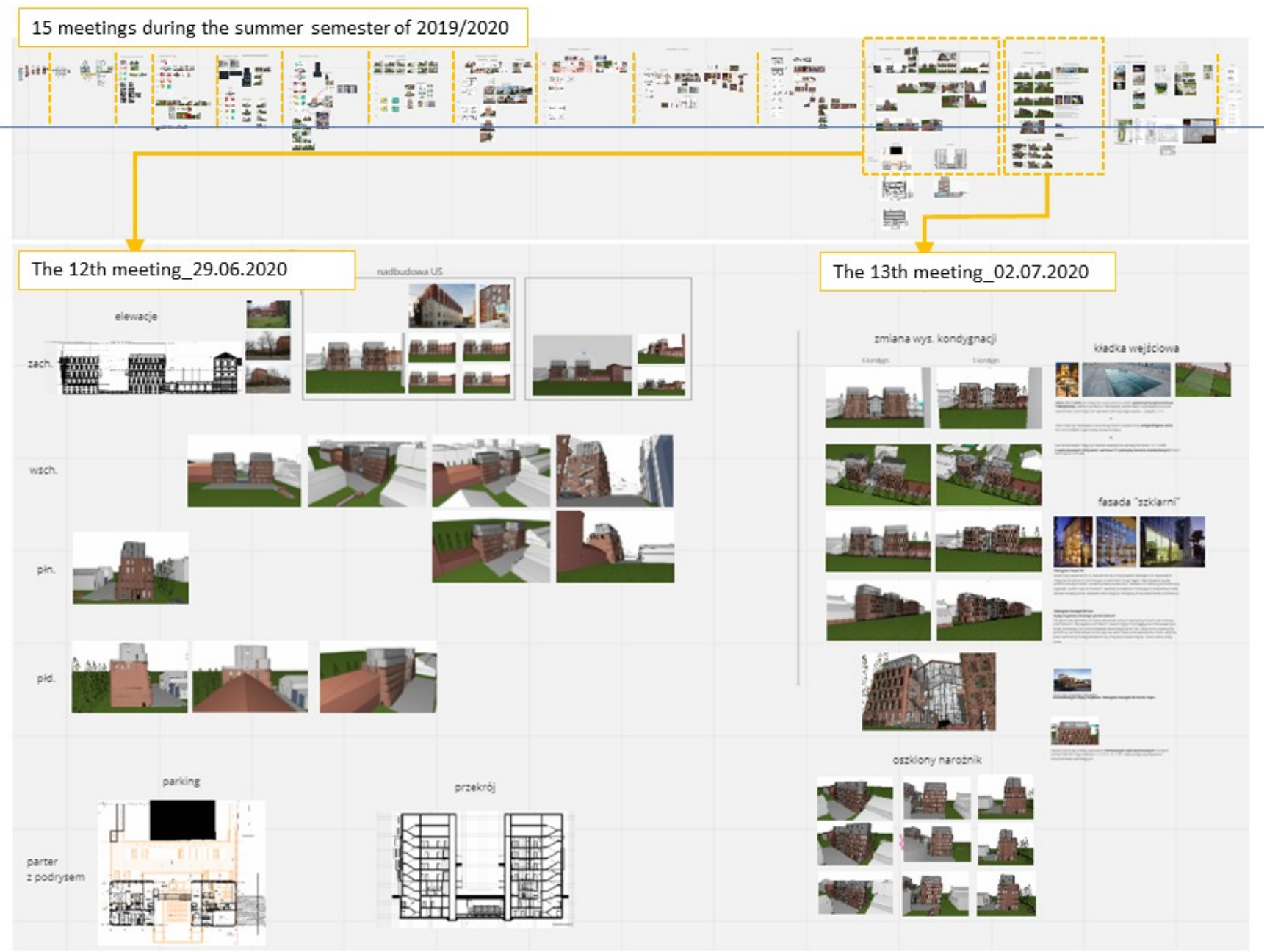

Figure 4. Project Journal (Student E-portfolio)—a sample Miro collaborative board presenting student's work through the whole semester (above). Close-up of the same board presenting results of two online meetings/consultations with the instructor (lower row).

Secondly, relating to the semester timeline, the original structure (i.e., schedule and timeframe) of the PDS courses were mainly kept and applied to the emergency VDS. Of course, practically, some adjustments had to be made. For example, the on-site activity of the PDS (i.e., study trip, tactile exercise of physical model making) had to be replaced by an online alternative (i.e., a virtual tour and online meeting with practicing architects, digital 3D-modeling). The switch from offline to online activities was supported by a set of valuable tools and methods proposed by the members in the TDT (Figure 3). The use of these tools went smoothly, avoiding delays in delivering content to the students. In this respect, all planned course objectives were reached, and no significant differences were notable in students' grades (compared to previous years in which PDSs were organised).

Thirdly, regarding lesson activities, the main observation based on Figure 3 and Table 1 is that the TDT members have succeeded in creating a full alternative to the original PDS activities. Although the organization of activities such as individual consultations, lectures, and project presentations was almost identical to the setup of original PDS activities, other activities required more creativity to come up with an online replacement. For example, setting up virtual site surveys or study trips requires a major mindset. In the absence of virtual reality equipment, which would have provided the most suitable alternative in our opinion, a number of applications (e.g., Google Earth, Google Arts \& Culture, Virtual $3 \mathrm{D}$ city model) were used intensively to guide these types of activities. Moreover, in the context of both individual and collaborative design exercises as well as the case study 
activity and the tactile exercise of model making, in the lockdown period our students were more than ever encouraged to learn the basics of digital drawing. Additional attention was also provided to the search for an appropriate platform to stimulate collaboration among students. Previous literature pointed out $[6,17,18]$ that in the past, this was (one of) the biggest stumbling block(s) when organizing VDSs. After thorough consideration, Miro-an online collaborative whiteboard platform - was selected; several features of this collaborative tool convinced the TDT members of its value, for example (1) seeing collaborators' cursors in order to track the precise contributions and changes of fellow students anytime and everywhere, (2) sharing the screen and presentations in an easy way, and (3) communicating directly with each other via the embedded video, chat, and commenting function allowing students to give feedback to each other and review each other's' work.

Finally, similar to the PDS, students submitted a portfolio in view of the assessment procedure. While the content of the portfolio remained the same, the format changed extensively. Instead of a physical folder (which was the format during pre-corona times), in the emergency VDS, the learning management system (i.e., MOODLE) of the university was used to collect all the evidence of the students. MOODLE allows students to collect all preferred drawings and visualizations in one place. Students added movies, 3D-animations, and virtual tours of buildings, enriching their online portfolio in an extended manner. The course facilitator had unlimited access to the work of students via the MOODLE platform and was able to monitor their progress rigorously. This unlimited access by the course facilitator is a major advantage over PDSs, where only during fixed times (i.e., physical presentations and consultations) students' work is visible and subject to feedback. Students highly appreciated the opportunity of feedback in every stage of their design process.

\section{Results}

In Table 1, the results of the TDT meeting are presented indicating the list of common teaching and learning methods and tools used in PDS translated into a VDS experience (illustrated in Figure 3). They show clearly that experienced architecture lecturers taking part in design and development of the emergency VDS expect that there is a wide chance to translate most PDS activities into emergency VDS in order to deliver effective online architecture education. Good examples here are individual consultations in the classroom supported by remote consultations via screen-sharing in between classes. Another example would be offering students both study trips and online meetings with practicing architects from different parts of the world. It is also expected by TDT that some of the proposed VDS activities could add even extra value to the teaching and learning process, e.g., engaging a larger group of students in consultations (see row $\mathrm{nr} 1$ in Table 1) or the way in which student portfolios can be compiled online. It is surprising and promising that teachers taking part in TDT, although having little experience with remote teaching, managed to propose concrete work-out solutions for each single PDS activity suggesting software, websites, and remote teaching platforms (see row nr 10 in Table 1, compare with Figure 4).

In Table 2, the results of the student questionnaire are presented. Specifically, in the tables, the average responses, the standard deviation - to show how spread out the data is - and the coefficient of variation - to indicate the variability associated with the questions-are included. The latter is, for most questions, rather low-it does not exceed $33.3 \%$ and for most questions is even between 0 and $16.5 \%$. This indicates that there is relatively little variation in responses which indicates a more reliable estimate. 
Table 2. Results of the survey-part 1. Questions 1-15 to choose from a 5-point Likert scale (ranging from 1 to 5).

\begin{tabular}{|c|c|c|c|c|c|}
\hline & & Questions & AVG & $\begin{array}{l}\text { Standard } \\
\text { Deviation }\end{array}$ & $\begin{array}{l}\text { Coefficient } \\
\text { of Variation }\end{array}$ \\
\hline & \multicolumn{5}{|c|}{$\begin{array}{l}\text { EVALUATION WHETHER THE COURSE MET THE NEEDS OF STUDENTS IN TERMS OF NR OF COURSE' PARTICIPANTS AND } \\
\text { PROVIDED NR OF CLASS HOURS }\end{array}$} \\
\hline & & \multicolumn{4}{|l|}{ Questions to choose from a 5 point Likert scale } \\
\hline 1 & & $\begin{array}{l}\text { The number of students in the design group was appropriate } \\
\text { and provided an opportunity to work comfortably on } \\
\text { my project }\end{array}$ & 4.14 & 0.60 & $14.49 \%$ \\
\hline 2 & & $\begin{array}{l}\text { The provided number of class hours was sufficient to develop } \\
\text { and consult on my project }\end{array}$ & 3.67 & 0.91 & $24.89 \%$ \\
\hline & \multicolumn{5}{|c|}{ EVALUATION OF THE EFFECTIVENESS OF PROPOSED TEACHING AND LEARNING METHODS IN VIRTUAL DESIGN STUDIO } \\
\hline & $\begin{array}{l}\text { Most common methods used in } \\
\text { Design Studio }\end{array}$ & Questions to choose from a 5 point Likert scale & & & \\
\hline 3 & $\begin{array}{l}\text { Individual consultations } \\
\text { (discussions with the instructor) }\end{array}$ & $\begin{array}{l}\text { I benefitted from joining online discussions with our } \\
\text { instructor to exchange ideas and contribute to my fellow } \\
\text { students' design process within so called accesible } \\
\text { individual consultancies }\end{array}$ & 4.31 & 0.91 & $21.18 \%$ \\
\hline 4 & Site visit & $\begin{array}{l}\text { Virtual site visits (Google Earth, Google Maps, virtual 3D city } \\
\text { model, etc.) and GIS Databases studies had a positive impact } \\
\text { on my design process }\end{array}$ & 3.98 & 0.67 & $16.90 \%$ \\
\hline 5 & $\begin{array}{l}\text { Study trip, f.e. visiting interesting } \\
\text { contemporary building }\end{array}$ & $\begin{array}{l}\text { Taking part in virtual tour and/or online meetings with } \\
\text { practicing architects had a positive impact on my } \\
\text { design knowlege }\end{array}$ & 4.31 & 0.56 & $12.90 \%$ \\
\hline 6 & $\begin{array}{l}\text { Tactile exercise of physical model } \\
\text { making }\end{array}$ & $\begin{array}{l}\text { Utilized digital model to represent my design instead of a } \\
\text { physical one enabled me to present it and develop it within } \\
\text { a team }\end{array}$ & 3.83 & 1.06 & $27.58 \%$ \\
\hline 7 & Pin-up board project presentation & $\begin{array}{l}\text { I benefitted from presenting my project on Miro } \\
\text { collaboration board }\end{array}$ & 4.50 & 0.55 & $12.12 \%$ \\
\hline 8 & Collaborative Design & $\begin{array}{l}\text { Virtual Design Studio provided alternative opportunities to } \\
\text { communicate with my teammates while working on } \\
\text { collaborative assignment }\end{array}$ & 4.86 & 0.35 & $7.20 \%$ \\
\hline \multirow[t]{3}{*}{9} & Student Portfolio & $\begin{array}{l}\text { Online presentation of each step of my design on Miro Board } \\
\text { process enabled me to observe my design process and } \\
\text { work progress }\end{array}$ & 4.76 & 0.61 & $12.81 \%$ \\
\hline & \multicolumn{5}{|c|}{$\begin{array}{l}\text { EVALUATION OF THE EFFECTIVENESS OF PROPOSED (EDUCATIONAL TECHNOLOGY) TOOLS WITHIN VIRTUAL DESIGN } \\
\text { STUDIO }\end{array}$} \\
\hline & Evaluated tool used in VDS & Questions to choose from a 5 point Likert scale & & & \\
\hline 10 & Zoom Meetings & $\begin{array}{l}\text { During the online studio process, I benefited from ZOOM } \\
\text { Video Meetings with Screesharing and Annotating Tools for } \\
\text { one-on-one meetings and group discussions }\end{array}$ & 4.40 & 0.82 & $18.58 \%$ \\
\hline 11 & Moodle Platform & $\begin{array}{l}\text { During the online studio process, I benefitted from alternative } \\
\text { research methods and digital resources available on Moodle } \\
\text { platform (e-library, web resource, etc.) }\end{array}$ & 4.79 & 0.41 & $8.57 \%$ \\
\hline \multirow[t]{3}{*}{12} & Chat Teams Messaging & $\begin{array}{l}\text { During the online studio process, I learned to use alternative } \\
\text { communication methods and benefitted from staying in touch } \\
\text { with our instructor and teammates in between the classes via } \\
\text { Teams Instant Messaging }\end{array}$ & 4.71 & 0.45 & $9.58 \%$ \\
\hline & \multicolumn{5}{|c|}{$\begin{array}{l}\text { EVALUATION OF THE INDIVIDUAL RESULTS GAINED WITHIN VIRTUAL DESIGN } \\
\text { STUDIO }\end{array}$} \\
\hline & Kind of skills developed in VDS & Questions to choose from a 5 point Likert scale & & & \\
\hline 13 & Time managment skills & $\begin{array}{l}\text { During the Virtual Design Studio process, I had the } \\
\text { opportunity to become more self-disciplined and more } \\
\text { organized in working on my project in my home environment }\end{array}$ & 4.79 & 0.51 & $10.73 \%$ \\
\hline 14 & Design skills & $\begin{array}{l}\text { During the Virtual Design Studio process, I had the } \\
\text { opportunity to improve my design skills }\end{array}$ & 4.29 & 0.50 & $11.71 \%$ \\
\hline \multirow[t]{2}{*}{15} & Presentation skills & $\begin{array}{l}\text { During the Virtual Design Studio process, I had the } \\
\text { opportunity to improve my presentation skills }\end{array}$ & 4.10 & 0.65 & $15.82 \%$ \\
\hline & & Avarege coefficient of variation: & & & $15.00 \%$ \\
\hline
\end{tabular}


The results of the first two questions show that students are mostly satisfied with the size of the class group and the provided number of class hours in the organized VDSs. This means that the organization and time-management of VDS courses-once participants get familiar with the used tools and platforms-does not demand crucial changes.

The results of the following seven questions give an idea of students' evaluation of the effectiveness of proposed teaching and learning methods in VDS. The average rate for these seven questions is 4.36, which clearly shows that most of the respondents evaluate the proposed methods as quite satisfactory. The opportunity to comfortably watch and listen to comments and sketches of the instructor while consulting their colleagues' projects via screen-sharing was rated high (i.e., an average rating of 4.31). This result can also be confirmed by what students repeatedly confirmed during classes. Specifically, several times throughout the VDSs, students mentioned that the share screen option enabled them to follow the discussion in a more comfortable way than was the case in face-to-face classes (PDS). In the latter, it is often difficult to see the details of fellow students' work. As in a face-to-face format only a few students can observe the projects at close range, the engagement of the others lowered as they often missed information and comments which were also relevant for their own projects. Exactly this problem was a main inspiration for the Educational Innovative Project named "Individual consultations. Make them visible!" which was carefully investigated and planned during the international Masters of Didactics program (see Figure 2).

The VDS activities that were significantly less appreciated by students are virtual site visits (average rating of 3.93) and digital modelling of representation of the project (average rating of 3.83). This clearly shows that-although the digital tools and platforms used in the VDSs (i.e., 3D Design Software, Map and GIS Databases) offer many benefits/possibilitiesexcluding site visits and tactile exercises of physical models entirely should be avoided. Site visits especially are crucial at the beginning of a PDS course; during these site visits students take photographs of the area as a basis for thorough analysis. In this respect, study visits are a necessary part of the students' design process. To deal with this situation, a potential solution could be to ask students to visit the site each individually and afterwards present their photographs and analysis during a teleconference meeting.

In comparison to the concept of the virtual site survey, the students were satisfied with taking part in virtual tours and online meetings with practicing architects, which they recognized as having a positive impact on their design knowledge (average rating of 4.31). These online meetings provide a unique opportunity for students to meet with, and ask questions to guest speakers (i.e., professional architects from Poland and abroad). Aside from the students' high satisfaction regarding this part of the VDS, for the instructors this activity was - from a logistical point of view - also much easier to organize.

Furthermore, the survey results showed that using digital tools and platforms can positively influence students' organization and time-management skills (question 13), as thanks to them the instructor can show them how to efficiently order all the information needed for the design process. The basic structure of the shared folders and files provided by the instructor on the Moodle platform indicated the deadlines, tidied the design process and helped to document and self-evaluate the project. In comparison, in PDSs, students had to plan and organize their files on their own and therefore struggled with finding their way in the development of the project.

Another virtual tool which was much appreciated by the students is Miro collaborative board. This is a virtual board where students can gather and manage all their drawings, animations, descriptions and comments and can combine them with external references (graphics, movie clips, photos, and website links). Students indicated to like the board as they feel free to compose their work the way they prefer. Additionally, the board offered them the opportunity to collaborate with their colleagues as well as their instructor. The main way in which Miro was used during the VDSs was in the form of a linear project journal. In this journal on Miro, each step of the design process is linked to a specific date. Once all the steps have been inputted into Miro, the students can have an in-depth look 
into their design process and how it evolved over time (see Figure 4). This so-called visual journal in Miro supported the development of students' self-assessment, reflection and action planning skills [37-39].

Next, the three questions focusing on the use of educational technology such as Zoom, Moodle and Chat Teams Messaging as digital platforms for socialization and production showed an average rate of 4.63. Although the students already use social media instruments very effectively, they are not familiar with formal digital communication tools which will most likely be important media for professional communication in their architectural career. In this respect, they highly appreciated the opportunity to get familiar with these educational technology tools via their participation in VDSs. Moreover, in the case of collaborative design tasks, the instructor (first author) experienced that students highly appreciate the opportunity to work in a team in their own intimate virtual space, such as via breakout rooms available in Zoom. Such a form of activity gives students in VDSs an opportunity to feel engaged and confident to talk in a small group [39], but also to socialize with each other, which is a crucial aspect of the design studio environment. Nevertheless, the instructor (host of the meeting) is still in charge of the whole meeting, can check students' work at any time, and offer support if necessary.

The results of the next three questions of the survey show that students are satisfied with their results gained within VDS in terms of time-management, design, and presentation skills (average rating of 4.63). The final assessment of their work also proves just that. In all studied courses, students had to complete four obligatory design assignments throughout the semester and at the end of the course defend their final project. The students' results showed that the level of their achievements is highly comparable to the results of the students taking part in the same course the year before-in a PDS format (before COVID-19).

The final two questions ask participants to compare their current experience in VDS with their previous experiences in PDS (see Table 3). The results reveal that more than $75 \%$ of the respondents think that VDS was beneficial to the development of their design skills in a similar way to PDS. This clearly shows that most of the proposed methods and tools - which were carefully chosen to replicate the experience of PSD—have done their job. However, even though the students were satisfied with the methods and tools used in VDS, if they had the opportunity to choose, only $5 \%$ would opt for a purely remote form of the course. The majority of students (nearly $86 \%$ ) would choose a mixture of both PDS and VDS, and as such for so-called blended learning.

Table 3. Results of the survey-part 2. Questions 16-17 with 3 optional answers.

\begin{tabular}{|c|c|c|c|}
\hline & $\begin{array}{l}\text { COMPARISON OF THE RESULTS GAINED WITH VIRTUAL DESIGN STUDIO } \\
\text { AND PHYSICAL DESIGN STUDIO }\end{array}$ & & \\
\hline \multirow[t]{2}{*}{16} & Virtual Design Studio was beneficial to development of my design skills... & $\begin{array}{l}\text { in similar way to Physicial Design Studio } \\
\text { much more than Physicial Design Studio } \\
\text { much less than Physicial Design Studio }\end{array}$ & $\begin{array}{l}76.19 \% \\
14.29 \% \\
4.76 \%\end{array}$ \\
\hline & $\begin{array}{l}\text { EVALUATION THE INDIVIDUAL EXPERIENCE IN TERMS OF CHOOSING } \\
\text { NEXT DESIGN STUDIO IN THE FUTURE }\end{array}$ & & \\
\hline \multirow[t]{3}{*}{17} & $\begin{array}{l}\text { Based on my experience with the course If I would have to choose the type } \\
\text { of my future Design Studio I would choose... }\end{array}$ & Physical Design Studio & $9.52 \%$ \\
\hline & & Virtual Design Studio & $4.76 \%$ \\
\hline & & $\begin{array}{l}\text { Mixture of Physical Design Studio and } \\
\text { Virtual Design Studio }\end{array}$ & $85.71 \%$ \\
\hline
\end{tabular}

\section{Discussion}

In contrast to learning experiences that are planned from the beginning and designed to be online, emergency remote teaching requires a quick shift to an alternate instructional delivery mode due to crisis circumstances as COVID-19 [40]. The main challenge of the present study - in which a physical design studio class for architecture students is transformed into an emergency virtual one-was to keep a cool head as university teachers 
and pay enough attention to the design and development process of the VDS in order to deliver effective online architecture education. As previous research has pointed out [41], the quality of online teaching hinges on well-considered design decisions, or in the words of Maher and colleagues: "we cannot just take a set of tools off the shelf and create a virtual design studio" [17] (p. 3). The use of technology implies a redefinition of instruction, rather than a substitution, in which technology is used for replicating existing offline learning activities, without any functional change or improvement of the learning experience [21]. Next, lessons learned from the design and implementation process of an emergency VDS at the Faculty of Architecture of Wroclaw University of Science and Technology are summed up.

\subsection{Design Process}

While the pandemic situation obliged us to stay at home, it is important that university teachers do not try to survive alone- each on their own island. To combine forces, a Teacher Design Team [32] of experienced architecture lecturers was set up in this study to make sure that the design and development of the emergency VDS happened in a systematic way. In this respect, future similar practices are advised-whether or not in a crisis situationto opt for the same (re)design procedure, whereby the ADDIE-model can function as a concrete step-by-step plan $[33,34]$. Following such-like step-by-step procedure to (re)design an entire course - or simply one lesson — bears witness to having a mindset of a lifelong learner. Continuing on this train of thought, participating on a regular basis in professional development initiatives—such as the Masters of Didactics programme-facilitates the redesign of university courses in a substantiated and significant manner. Plus, in the same breath, this is a response to the warning from Chen and You [6], who pointed out that most instructors are not well-prepared for the organization of VDS, and need time to get used to new teaching methods and technological tools.

\subsection{Implementation Process}

As the success of VDS depends on students' perceptions too [6,18], a survey was administered to all enrolled students with the aim to evaluate the implementation of the emergency VDS. The survey revealed important insights regarding students' opinions on design studio courses on online platforms. In line with the observation of Wragg [36] who refers to the importance of transferring a PDS into a VDS in an iterative way, these insights can be helpful to improve the specific VDS designed in the present study as well as serve as general design guidelines for future architecture education.

Firstly, the vast majority of students were enthusiastic about the tools and methods that were used in the emergency VDS. In particular, the opportunity to observe projects of fellow students via the share-screen option of the virtual classroom was mentioned as a major added value. Compared to the physical version of the design studio, in which all students collect around a table to watch colleagues' projects, VDS makes it much easier to see the details and to follow the instructor-student feedback conversation. While the sharescreen option was perceived by both teachers and students as the most valuable general tool in online architecture education, the planned virtual site visits (e.g., via Google Earth) and exclusively digital modelling of architecture projects by using 3D Design Software omitting physical model making, especially in the initial design phase, were less appreciated. Even 20 years after Maher et al. [15] wrote that VDS can lead to frustrations when teachers' and students' expectations reach further than the technological capabilities of tools, the current study confirms that this is still the case despite major digital evolutions in recent years.

Secondly, while interaction and collaboration between several stakeholders (e.g., students, teachers, community) are key ingredients of DS, the literature review $[11,19,20]$ showed that these elements were the main obstacles of VDSs in the past. Based on this finding, the team who designed the VDS consciously opted for the integration of online meetings with practicing architects in the VDS schedule. This design decision is also in line with research of Ioannou [9] who emphasized that virtual architectural design 
studios offer the possibility to extend students' knowledge base by discussing their views with the community. The results of our student survey showed that students recognize online meetings with (inter)national professional architects as having a positive impact on their design knowledge. An extra advantage is that the instructors of the current study experienced that the online character of the DS simplifies the organization of these meetings.

Next to that, Kvan's [16] research has taught us that it is necessary to think carefully about how to set up online student-student and teacher-student interactions and collaboration. When it comes to the online individual consultations (Zoom, Microsoft Teams) that students had with their instructor, the students rated this way of exchanging ideas as extremely positive. In order to stimulate interactions among students, the use of 'break-out rooms' during Zoom or MS Teams meetings are also highly recommended. With regard to design collaborations between students-from all tested platforms throughout the preparation phase- the collaborative board Miro seemed best suited to meet the learning objectives of the DS. The student survey confirmed this; the students see Miro as a highly interesting platform to create pin-up board project presentations, to compile a student portfolio that stimulates self-assessment during the architectural design process, and to provoke online communication and collaboration with teammates (Figure 4). Based on the consideration of Fleischmann [11], well-known social media platforms were not used to stimulate design collaborations among students. Where social media platforms were not originally created for educational purposes, the instructor and students made an appeal to Facebook and the visually driven platform Instagram in the context of the virtual study visit. Students were not explicitly questioned about this educational use of social media; however, the main instructor had the impression that students were using them in order to find actual/up-to-date information and photos of the site chosen for the project they have been working on.

Contrary to previous studies (e.g., $[11,19,20])$, the students of the current study do not describe online communication and collaboration as a pitfall in this emergency VDS. More so, in the current study, the opposite is true. Students accentuate that with a view to their future professional career, they found the VDS an interesting experience to get familiar with communication software such as Zoom and Microsoft Teams. On top of that, compared to the experiences the students of this case study have with PDS, the majority believe that the emergency VDS contributes equally or even more to the development of their design and presentation skills. A possible explanation for the smooth online communication and collaboration identified in this study might be that most of the students already knew each other and their instructor before the start of fully remote teaching caused by COVID-19. The basis for the online collaboration may have been formed during face-to-face meetings taking place right before lockdown of the university at the beginning of summer semester of 2019/2020 and winter semester of 2020/2021.

Altogether, compared to the findings of Fleischmann [11], if offered the choice, the vast majority of students prefer blended design studios, which combine the benefits of both PDS and VDS, as the dominant model in future architecture education. Further exploration and evaluation of the tools and methods proposed by TDT for PDS and VDS (Tables 1 and 2) showed that in the case of blended learning both lists should not be treated exclusively but as a complete set. As a result, they could evolve, offering many more options and sources of architectural knowledge as well as skills, and widening the community engaged with the design studio. This finding was also reported by Fleischmann [11]. This result further supports the idea of Pektas [22] and Ioannou [10] too, who already made a case for blended DS. Since blended DS is in its infancy, further research should be undertaken to investigate which design principles are crucial in such a learning environment. More suggestions for further research and how these inspirations can counter the limitations of the current research are discussed below. 


\subsection{Limitations and Further Research}

As for every research, the present study is also subjected to certain limitations that can guide future research. First, the current case study revealed a number of design guidelines that are more generally applicable to blended DSs worldwide. These data, however, must be interpreted with caution because of its limited number of participants, which prevents generalization. Second, in this research only descriptive statistics were used. For the purpose of the study—namely gaining insight into the redesign and how this was perceived by students-these basic analyses were appropriate. However, in future research, and with the aim to pinpoint the significance of VDS or blended DS regarding students' results and/or satisfaction, more advanced analyses are needed. Third, by using a student survey, the current study's results provide a general picture of students' perceptions. In future studies, it is advisable to involve students more thoroughly in the (re)design process of a DS. On the one hand, this is possible at the beginning of the trajectory. Because of the emergency situation, students' expectations of the VDS were not gathered; nevertheless, questioning stakeholders' needs is a very interesting strategy to commence a redesign process. On the other hand, next to the survey, more in-depth feedback on the implementation of the VDS could be collected by using qualitative research methods too like semi-structured interviews or focus groups. By doing so, we hope that future research can uncover all essential pieces of the blended DS puzzle.

\section{Implications}

Worldwide, the COVID-19 pandemic has caused large disruptions in (higher) education. In Poland, all universities were forced to close their doors and had to switch to emergency remote teaching. In architecture education-under normal circumstancesstudents are often trained via PDSs. Face-to-face student-teacher and student-student interactions are the backbone of these classes. In next to no time, these PDSs had to be redesigned with the aim to organize them in a completely online manner. Using a case study approach, the present paper described the systematic process of this redesign and how it has been perceived by students enrolled in these DSs. Particularly, the redesign of the DSs as a result of the organized TDT as well as the findings of the survey administered from all students enrolled in the DSs were presented and linked to well-known educational literature regarding remote and physical learning.

The implications derived from the current study's results can be formulated in three important lessons regarding the design and implementation process of emerging VDSs. First, the study showed that the (re)design of a course — even in emergency circumstancesprofits from a well-thought out and systematic plan. In this respect, following a stepby-step procedure-such as the ADDIE-model—can help future teacher design teams to offer a high-quality course to their students. Second, data revealed that students assessed some tools and methods within the VDSs as highly positive (e.g., online meetings with practicing architects, Miro) and even better than methods used in traditional formats (e.g., shared-screen options), while other tools led to frustrations as they could not replace the advantages of students' physical attendance (e.g., virtual site visits). In this respect, we recommend teachers who aim to organise VDSs to carefully think about, and search for, the tools and strategies they will implement. Preferably-teachers can organise this search together with their students, for example by asking them to participate in a trial run of the selected tools. Finally, and in line with previous research from Pektas (2012), the study showed that the vast majority of students articulated a preference for blended design studios, which offer a balanced format of both virtual and physical educational elements.

\section{Conclusions}

On a final note, this study shows that even when conditions are extremely difficult-in this case being forced to implement emergency VDSs-high-quality education can be offered to students. Realizing high-quality education 'even when under pressure', requires teachers and students alike to join forces. Together—with efforts from both sides—anything 
becomes possible. Or to state this with a well-known English proverb: "When the going gets tough, the tough get going".

Author Contributions: Conceptualization, E.K.-S.; methodology, E.K.-Ś., B.A. and L.T.; investigation, E.K.-Ś., B.A. and L.T.; resources, E.K.-Ś., B.A. and L.T.; data curation, E.K.-Ś.; writing—original draft preparation, E.K.-Ś.; writing—review and editing, E.K.-Ś., B.A. and L.T.; visualization, E.K.-Ś. All authors have read and agreed to the published version of the manuscript.

Funding: This research received no external funding. However, the educational methods and tools applied for the research were introduced within the Masters of Didactics program at Ghent University founded by European Funds-Knowledge Education Development, The Republic of Poland, European Social Fund.

Institutional Review Board Statement: Not applicable.

Informed Consent Statement: Not applicable.

Data Availability Statement: The analyzed data is contained in the quoted articles and their data extensions.

Conflicts of Interest: The authors declare no conflict of interest.

\section{References}

1. Salama, A.M. Spatial Design Education. New Directions for Pedagogy in Architecture and Beyond; Routledge: London, UK, 2015.

2. Tokman, L.Y.; Yamacli, R. Reality-based design studio in architectural education. J. Archit. Plan. Res. 2007, 24, 245-269.

3. Dinham, S. An Ongoing Qualitative Study of Architecture Studio Teaching [Microform]: Analyzing Teacher-Student Exchanges. ASHE Annual Meeting Paper; ERIC Clearinghouse: Washington, DC, USA, 1987; p. 37.

4. Lizondo-Sevilla, L.; Roig, L.B.; Ribera, C.F; Ramón, J.L.A. Teaching Architectural Design through Creative Practices. METU J. Fac. Archit. 2019, 36, 41-60. [CrossRef]

5. Soliman, A.M. Appropriate teaching and learning strategies for the architectural design process in pedagogic design studios. Front. Arch. Res. 2017, 6, 204-217. [CrossRef]

6. Chen, W.; You, M. Student response to an Internet-mediated industrial design studio course. Int. J. Technol. Des. Educ. 2010, 20, 151-174. [CrossRef]

7. Kirschke, P.; Komarzyńska-Świeściak, E. Wystawy Problemowe-Wrocław na Miarę Naszych Możliwości. Akupunktura Miasta: Dolnośląski Festiwal Architektury DoFA' 13; Stowarzyszenie Architektów Polskich. Oddział we Wrocławiu: Wrocław, Poland, 2013; pp. 66-75. (In Polish)

8. Bada, S.O.; Olusegun, S. Constructivism Learning Theory: A Paradigm for Teaching and Learning. IOSR J. Res. Method Educ. 2015, 5, 66-70.

9. Palincsar, A.S. Social constructivist perspectives on teaching and learning. Annu. Rev. Psychol. 1998, 49, 345-375. [CrossRef]

10. Ioannou, O. Opening up design studio education using blended and networked formats. Int. J. Educ. Technol. High. Educ. 2018, 15. [CrossRef]

11. Fleischmann, K. Online design education: Searching for a middle ground. Arts Humanit. High. Educ. 2020, 19, 36-57. [CrossRef]

12. Masdéu, M.; Fuses, J. The Design Studio as a New Integrative and Experimental Learning Space: The Pedagogical Value of Implementing BIM, Parametric Design and Digital Fabrication in Architectural Education. In Proceedings of the ATINER Conference, 10th Annual International Conference on Languages \& Linguistics, Athens, Greece, 3-6 July 2017.

13. Pak, B.; Verbeke, J. Design Studio 2.0: Augmenting Reflective Architectural Design Learning. J. Inf. Technol. Constr. 2012, 17, 502-519.

14. Devetaković, M.; Arsić, P.; Nikolić, I.; Petruševski, L.; Mitrović, B. Integration of e-learning concepts in urban design studio: The case of a virtual learning environment supporting a specific educational mode. In Proceedings of the YU Info 2011 Conference, Kopaonik, Serbia, 7 March 2011; pp. 26-32.

15. Helenowska-Peschke, M. Kształcenie hybrydowe-Wykorzystanie e-podręczników w dydaktyce na poziomie akademickim. Komputer. In Proceedings of the Edukacja: 19. Ogólnopolskie Sympozjum Naukowe: Ktme, Kraków, Poland, 25-26 September 2009; pp. 87-91. (In Polish)

16. Komez, E.; Pinar, E.; Gursel, D.I.; Arslan, P.; Bas, B.F. Teaching Architectural Design Studio Remotely: The Introduction to Architectural Design Course at METU. J. Des. Studio 2020, 2, 153-157.

17. Maher, M.L.; Simoff, S.J;; Cicognani, A. Understanding Virtual Design Studios; Springer: Berlin, Germany, 1999.

18. Yee, S. Building Communities for Dsign Education: Using Telecommunication Technology for Remote Collaborative Learning using Tele-Communication Technology for Remote Collaborative Learning. Ph.D. Thesis, MIT, Cambridge, MA, USA, 2001.

19. Kvan, T.; Maher, M.; Cheng, N.; Schmitt, G. Teaching Architectural Design in Virtual Studios. In Computing in Civil and Building Engineering, Proceedings of the 8th International Conference on Computing in Civil and Building Engineering, ASCE 2000, Stanford, CA, USA, 14-16 August 2000; Fruchter, R., Feniosky, P.-M., Roddis, W.M.K., Eds.; ASCE: Reston, VA, USA, 2000; pp. 162-169. 
20. Senyapili, B.; Karakaya, A.F. The Future Setting of the Design Studio. Open House Int. 2009, 34, 104-112. [CrossRef]

21. Boelens, R.; De Wever, B.; Voet, M. Four key challenges to the design of blended learning: A systematic literature review. Educ. Res. Rev. 2017, 22. [CrossRef]

22. Pektas, S.T. The Blended Design Studio: An Appraisal of New Delivery Modes in Design Education. Procedia Soc. Behav. Sci. 2012, 51, 692-697. [CrossRef]

23. Mc Clean, D.; Hourigan, N. Critical Dialogue in Architecture Studio: Peer Interaction and Feedback. J. Educ. Built Environ. 2013, 8, 35-57. [CrossRef]

24. Barbour, M.; LaBonte, R.; Kelly, K.; Hodges, C.; Moore, S.; Lockee, B.; Trust, T.; Bond, M. Understanding Pandemic Pedagogy: Differences Between Emergency Remote, Remote and Online Teaching. State Nation K-12 e-Learn. Can. 2020. [CrossRef]

25. Whittle, C.; Tiwari, S.; Yan, S.; Williams, J. Emergency remote teaching environment: A conceptual framework for responsive online teaching in crises. Inf. Learn. Sci. 2020, 121, 311-319. [CrossRef]

26. Hartley, J. Case study research. In Essential Guide to Qualitative Methods in Organizational Research; Cassell, C., Gillian, S., Eds.; Sage Publications Ltd.: London, UK, 2004; pp. 323-333.

27. Yin, R.K. Case Study Research: Design and Methods; Sage Publications: Thousand Oaks, CA, USA, 1994.

28. Harrison, H.; Birks, M.; Franklin, R.; Mills, J. Case Study Research: Foundations and Methodological Orientations. Forum Qual. Soc. Res. 2017, 18. [CrossRef]

29. Flyvbjerg, B. Case Study. In The Sage Handbook of Qualitative Research, 4th ed.; Denzin, N.K., Lincoln, Y.S., Eds.; Sage: Thousand Oaks, CA, USA, 2011; pp. 301-316.

30. Dong, E.; Du, H.; Gardner, L. An interactive web-based dashboard to track COVID-19 in real time. Lancet Infect. Dis. 2020, 20, 533-534. [CrossRef]

31. Nalaskowski, F. Indoor education in Poland during the Covid-19. In Proceedings of the DIALOGO-CONF 2020, Constanta, Romania, 3-12 November 2020; Volume 6, pp. 57-62.

32. Handelzalts, A. Collaborative curriculum development in teacher design teams. In Collaborative Curriculum Design for Sustainable Innovation and Teacher Learning; Pieters, J., Voogt, J., Roblin, N.P., Eds.; Springer International Publishing AG: Berlin/Heidelberg, Germany, 2019; pp. 159-173.

33. Adams, B.; Rotsaert, T.; Schellens, T.; Valcke, M. Pre-service teachers as designers in the context of advertising literacy education. Educ. Des. Res. 2020, 3. [CrossRef]

34. Gustafson, K.L.; Branch, R.M.; Alpert, S.A. Survey of Instructional Development Models, 4th ed.; ERIC Clearinghouse on Information \& Technology: Syracuse, NY, USA, 2002.

35. Master of Didactis. Available online: https://www.ugent.be/pp/onderwijskunde/en/projects/mastersofdidactics.htm (accessed on 2 April 2021).

36. Wragg, N. Online communication design education: The importance of the social environment. Stud. High. Educ. 2020, 45, 2287-2297. [CrossRef]

37. Syzdykova, Z.; Koblandin, K.; Mikhaylova, N.; Akinina, O. Assessment of E-Portfolio in Higher Education. Int. J. Emerg. Technol. Learn. 2021, 16, 120-134. [CrossRef]

38. Yang, M.; Wang, T.; Lim, C.P. E-Portfolios as Digital Assessment Tools in Higher Education. In Learning, Design, and Technology; Spector, M., Lockee, B., Childress, M., Eds.; Springer International Publishing: Cham, Switzerland, 2017; pp. 1-23.

39. Mohammadi, M.; Esmaeily, M.; Nik, A. The effectiveness of group consultation in the method of transactional analysis over the student's communicative skills. Procedia Soc. Behav. Sci. 2010, 5, 1490-1492. [CrossRef]

40. Hodges, C.; Moore, S.; Lockee, B.; Trust, T.; Bond, M. The Difference between Emergency Remote Teaching and Online Learning. 2020. Available online: https:/ / er.educause.edu/articles/2020/3/the-difference-between-emergency-remote-teaching-andonline-learning (accessed on 18 July 2021).

41. Means, B.; Bakia, M.; Murphy, R. Learning Online: What Research Tells Us About Whether, When and How; Routledge: New York, NY, USA, 2014. 